\title{
Crosstalk in human brain between globoid cell leucodystrophy and zinc-alpha-2-glycoprotein (ZAG), a biomarker of lipid catabolism
}

\author{
Danuta Maślińska ${ }^{1,2}$, Milena Laure-Kamionowska ${ }^{1}$, Stawomir Maśliński \\ ${ }^{1}$ Department of Experimental and Clinical Neuropathology, M. Mossakowski Medical Research Centre, Polish Academy of Sciences, \\ Warsaw, ${ }^{2}$ Department of Pathophysiology, Warsaw Medical University, Warsaw, Poland
}

\begin{abstract}
Zinc-alpha-2-glycoprotein (ZAG) is a protein identified as a lipid-mobilizing factor participating in a lipid catabolism. In spite of intensive studies conducted during last five decades, the role of this protein in processes of neurodegeneration remains unclear. The aim of our study was to examine the presence of ZAG protein in the brain of patients with Krabbe's disease, which is considered as a psychosine lipidosis caused by a mutation of a known gene. We found intracellular and extracellular localization of ZAG in the brain of Krabbe's disease patients but in the brain of control age-matched patients, ZAG was not detected. Distribution of ZAG in the brain suggests that the influx of ZAG into the brain involved a blood-brain barrier mechanism and adenoreceptors localized on astrocytes and some neurons.
\end{abstract}

Key words: Krabbe's disease, globoid cell leucodystrophy, zinc-alpha-2-glycoprotein, cachexia, human brain, hypertrophied astrocytes, choroid plexus.

\section{Introduction}

The diagnosis of several neurodegenerative diseases is often difficult though it could be greatly enhanced by the use of disease-specific biomarkers [27]. In order to expand the search for such biomarkers, two-dimensional electrophoresis (2-DE) was previously used to separate proteins from different body fluids $[6-8,26,35]$. This method appeared useful not only for an effective identification of several proteins and their isoforms but also for an evaluation of quantitative and qualitative protein differences between the diseased and normal body state [11].

In the cerebrospinal fluid (CSF), a number of neuron-specific proteins and cytoskeleton markers have been found [21] and in the subsequent investigations, the important role of these proteins in the pathogenesis of some neurodegenerative processes was documented [1,3,28]. Zinc-alpha-2-glycoprotein (ZAG) was also separated by 2-DE, but in spite of intensive studies conducted during the last five decades the role of this protein in neurodegenerative processes remains unclear. ZAG is $41 \mathrm{kDa}$ soluble protein first isolated from human plasma [4]. It was identified in different body fluids and organs, such as the liver, breast, lung, prostate and in both visceral and subcutaneous adipose tissue, suggesting its widespread exocrine function [2,17,30]. Finally, a role of ZAG was identified in patients with cancer 
cachexia as the lipid mobilizing factor associated with lipid catabolism of adipose tissue [13]. ZAG stimulates lipolysis through interaction with adenoreceptors [24] and plays an important role in the function of brown adipose tissue, lipid catabolism and expenditure of energy from the body [13]. In the CSF, the level of ZAG seems to be connected precisely with pathological processes [11] but the presence of this protein in the brain during the process of neurodegeneration was not examined. The aim of the present study was to detect ZAG protein in the brain of patients with Krabbe's disease that is the most common, severe, rapidly progressing neurodegeneration $[9,19]$ and invariably fatal inherited metabolic disease caused by a known gene mutation $[16,29,34]$.

\section{Material and methods}

Brain samples were obtained at autopsy of 11 patients with Krabbe's disease (globoid cell leukodystrophy) who had died at 7-25 months of age. Tissue was fixed in formalin, embedded in paraffin, stained and clinical diagnosis was confirmed by neuropathological examination of cerebral sections in the Department of Developmental Neuropathology, Polish Academy of Sciences.

For the purpose of the present study, the brain paraffin blocks were drawn from the archive of the Medical Research Institute (Polish Academy of Sciences, Warsaw, Poland). The blocks containing samples of different brain regions were cut to $8 \mu \mathrm{m}$ thick serial sections and were used for immunohistochemical study. Some sections were stained with cresyl violet for routine histological examination.

The same procedures of tissue preparation, immunohistochemical and morphological staining were used for the sections obtained from the brains of age-matched 11 control patients.

\section{Immunohistochemistry}

Immunohistochemistry was performed using the alkaline phosphatase-avidin-biotin conjugate or avidin-biotin-peroxidase complex system, according to the manufacturer's recommendations (Vectastain Elite ABC Peroxidase Kit; Vector Laboratories).

Briefly, sections were dewaxed and hydrated through descending alcohols to water. For non-enzymatic antigen retrieval, sections were heated in $0.01 \mathrm{M}$ sodium citrate buffer $\left(\mathrm{pH} \mathrm{6.0)}\right.$ to $95^{\circ} \mathrm{C}$ and allowed to cool for $20 \mathrm{~min}$ at room temperature and washed with PBS. Then, sections were incubated in methanol/3\% $\mathrm{H}_{2} \mathrm{O}_{2}$ solution for 20 min to quench endogenous peroxidase. Washed again in PBS and blocked with a solution containing PBS/5\% normal serum of goat, rabbit or mouse for $2 \mathrm{~h}$ at room temperature, sections were incubated overnight at $4^{\circ} \mathrm{C}$ in solutions of primary antibodies (Table I).

In addition, glial cells were identified with: polyclonal glial fibrillary acidic protein (GFAP) antibodies generated against $\mathrm{n}$-terminus (sc-6171) and c-terminus (sc-6170) domains of human GFAP origin (Santa $\mathrm{Cruz}$ ) and Ferritin polyclonal antibody generated against human full length ferritin (DAKO).

Immunoreactions were visualized using biotinylated secondary antibodies and ABComplex/HRP or an alkaline phosphatase-avidin-biotin conjugate. Then, sections were lightly counterstained with Mayer's haematoxylin.

For negative controls, primary antibodies were replaced with an appropriate isotypic normal mouse, rabbit or goat immunoglobulin fraction at matched protein concentration. These were included for the examination of each specimen and consistently produced negative results.

Table I. Antibodies generated against different domains of human zinc-alpha-2-glycoprotein (ZAG), source and dilution used in the study

\begin{tabular}{|c|c|c|c|c|c|c|}
\hline Antibody type & $\begin{array}{l}\text { Antibody } \\
\text { source }\end{array}$ & Catalogue & Antigen origin & Antigen domain & Dilution & $\begin{array}{l}\text { Blocking } \\
\text { peptide }\end{array}$ \\
\hline Monoclonal & Mouse & sc-21720 & Human & $\mathrm{nm}$ & $1: 100$ & na \\
\hline Monoclonal & Mouse & SC-13585 & Human & $\mathrm{fl}$ & $1: 100$ & na \\
\hline Monoclonal & Mouse & sc-21721 & Human & $\mathrm{nm}$ & $1: 100$ & na \\
\hline Polyclonal & Goat & sc- 11238 & Human & ir & $1: 50$ & SC-11238 P \\
\hline
\end{tabular}

sc - Santa Cruz, USA, na - not available, nm - not mentioned, $f l$ - full length of ZAG, ir - internal region of ZAG 


\section{Results}

The presence of ZAG protein was detected with a battery of different mono- and polyclonal antibodies generated against various fragments of human ZAG protein. The most precise localization of the antigen in human paraffin brain sections was found using a polyclonal antibody produced by goat against the internal region (ir) of ZAG protein. This antibody (sc-11238), as well as all other antibodies and chemicals used in the present study, were purchased from Santa Cruz Laboratories (USA).

In the brain of all patients affected by Krabbe's disease, ZAG protein was found. The strong immunoreactivity documenting the presence of ZAG was localized precisely around capillaries of brain blood vessels. Such capillaries were scattered throughout the grey and white matter of brain hemispheres and cerebellum (Fig. 1). They were most numerous in the brain regions with a well-preserved structure of the nervous tissue. Blood vessels of a larger lumen diameter than capillaries contained strong immunoreactive blood serum but they were never surrounded by extracellular ZAG immunoreactivity (Fig. 2) as capillaries were. In brain regions where the white matter lesion was pronounced and where a spongy state developed, the presence of ZAG was detected in GFAP immunoreactive and hypertrophied astrocytes (Fig. 3). Intracellular localization of ZAG was found also in Purkinje cells and in all forms of their subsequent degeneration (Fig. 4). Ramified microglia as well as the small-sized and large-sized globoid cells being immunoreactive for ferritin did not contain ZAG protein.

The presence of ZAG was found on epithelial cells of the choroid plexus of patients with Krabbe's disease (Fig. 5) but not in control patients (Table II).

\section{Discussion}

Krabbe's disease is an autosomal recessive disorder primarily affecting infants. In the great majority of cases, the symptoms appear during the first year of life. In a few cases, the symptoms come on during the first decade. Known mutations of the beta-galactosylcerebrosidase gene cause a dysfunction of lysosomal enzyme, which participates in the degradation of several glycosphingolipids [16,34], and lead to the accumulation of the galactosylsphingosine (psychosine) in the nervous system [14] and peripheral organs [15]. Thus, Krabbe's disease is considered as a psychosine lipidosis.

Although psychosine is highly cytotoxic metabolite, which plays a critical role in the pathogenesis
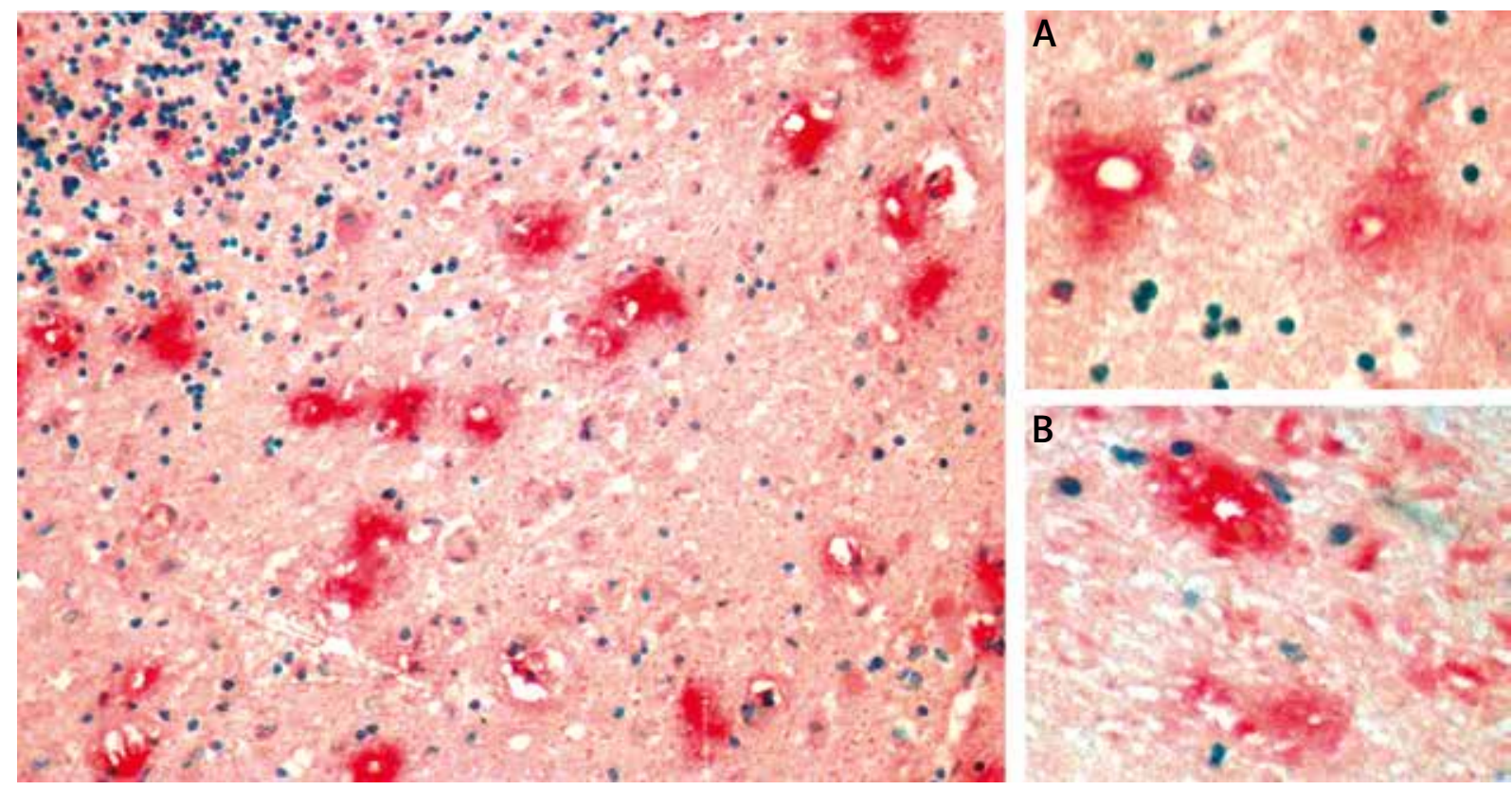

Fig. 1. Extracellular distribution of ZAG around numerous blood capillaries in the brain of a patient with Krabbe's disease. Magn. $\times 100$. Inserts: A) Capillaries of cerebellar white matter. Magn. $\times 200$; B) capillaries in cerebellar grey matter. Magn. $\times 200$. 

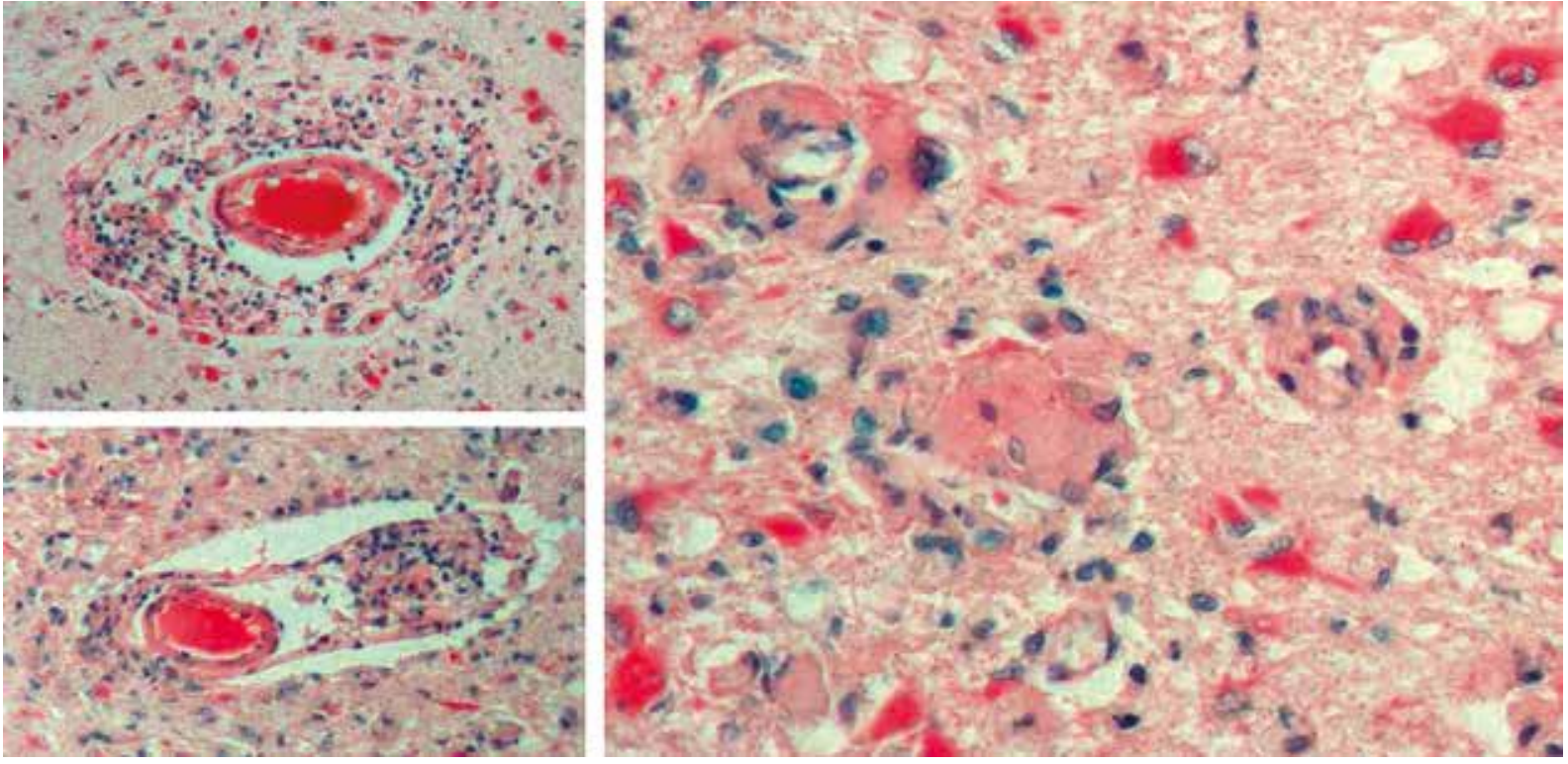

Fig. 2. ZAG detected in blood plasma of numerous brain blood vessels, in astrocytes but not in proliferated epithelial cells. Magn. $\times 100$.
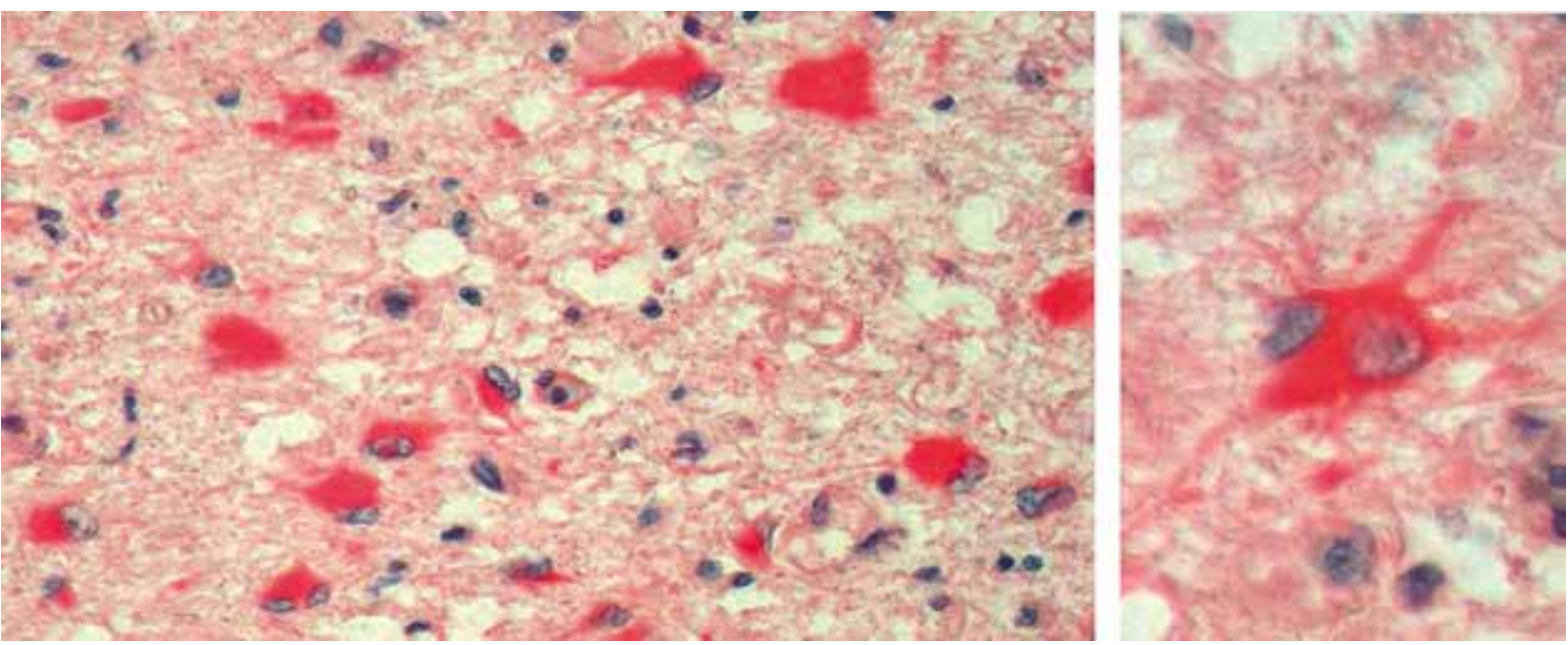

Fig. 3. Hypertrophic astrocytes containing ZAG. Brain areas undergoing spongy degeneration. Magn. $\times 200$. Insert magn. $\times 400$.

of the infantile form of Krabbe's disease, the mechanism of its action in the pathophysiology of the disease has not yet been fully elucidated. One of the hypotheses suggests that psychosine mediates its toxic effect in cells by inhibition of the electron transport chain in mitochondria $[10,31]$.

In such cells, the loss of mitochondrial membrane potential depends on the activation of the uncoupling protein (UCP) which expression, on the other hand, is mediated by zinc-alpha2-glycoprotein (ZAG) [25].

According to results of our present study, which documents for the first time that ZAG is present in the brain of patients with Krabbe's disease, ZAG could be directly involved in the mechanism of psychosine neurotoxicity. Moreover, we observed that the main source of the brain ZAG was that circulating in blood plasma, which was strongly ZAG immuno-positive within the lumen of numerous blood vessels. However, only brain capillaries were surrounded by immuno-positive ZAG antigen suggesting that the influx transport of ZAG involves blood-brain barrier mechanisms that are localized on endothelium of these smallest brain blood vessels. 

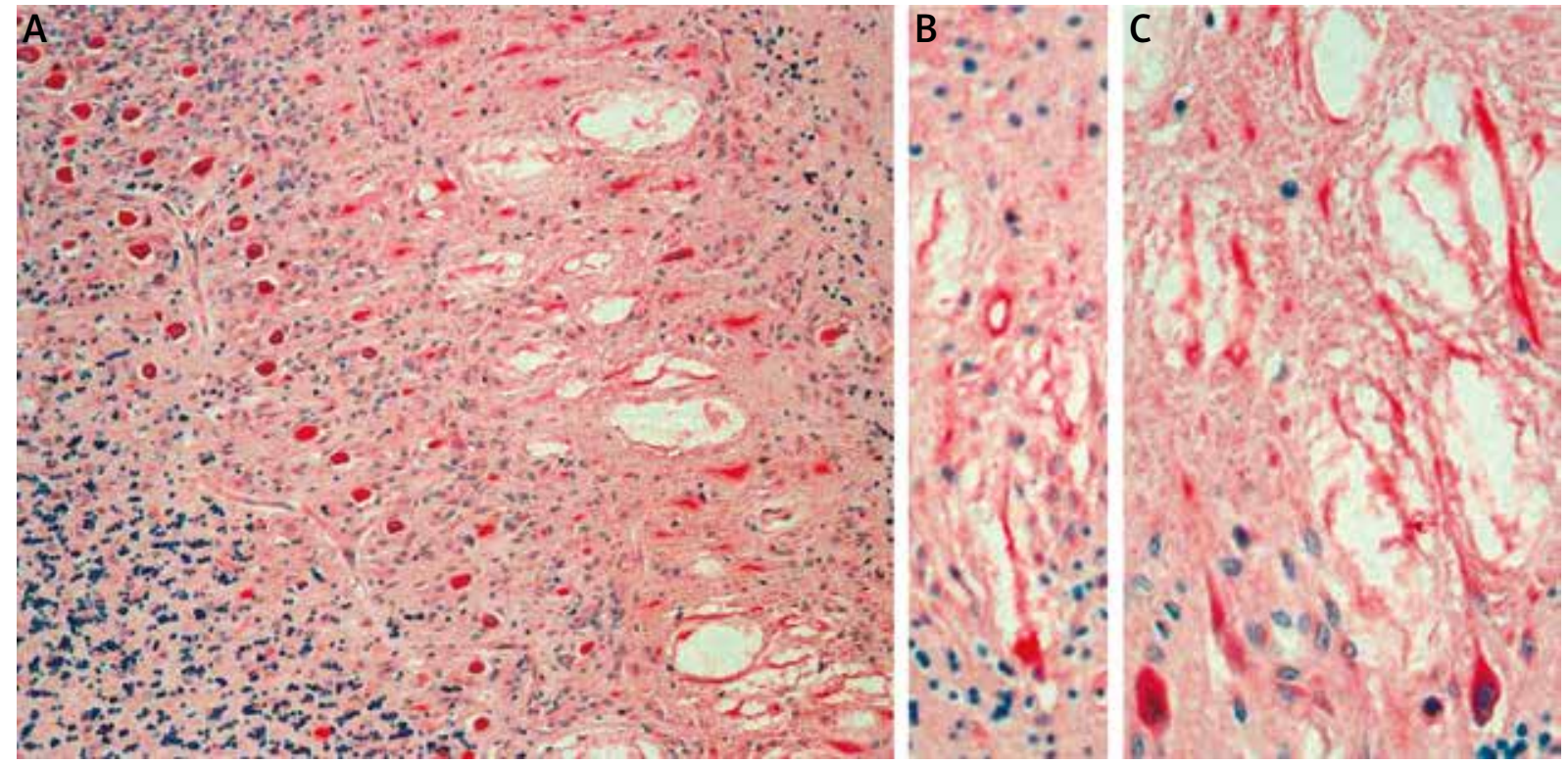

Fig. 4. ZAG localized in the body of Purkinje cells and in their dendritic trees undergoing degeneration in the course of Krabbe's disease. A) Magn. $\times 100$; B-C) Magn. $\times 400$.
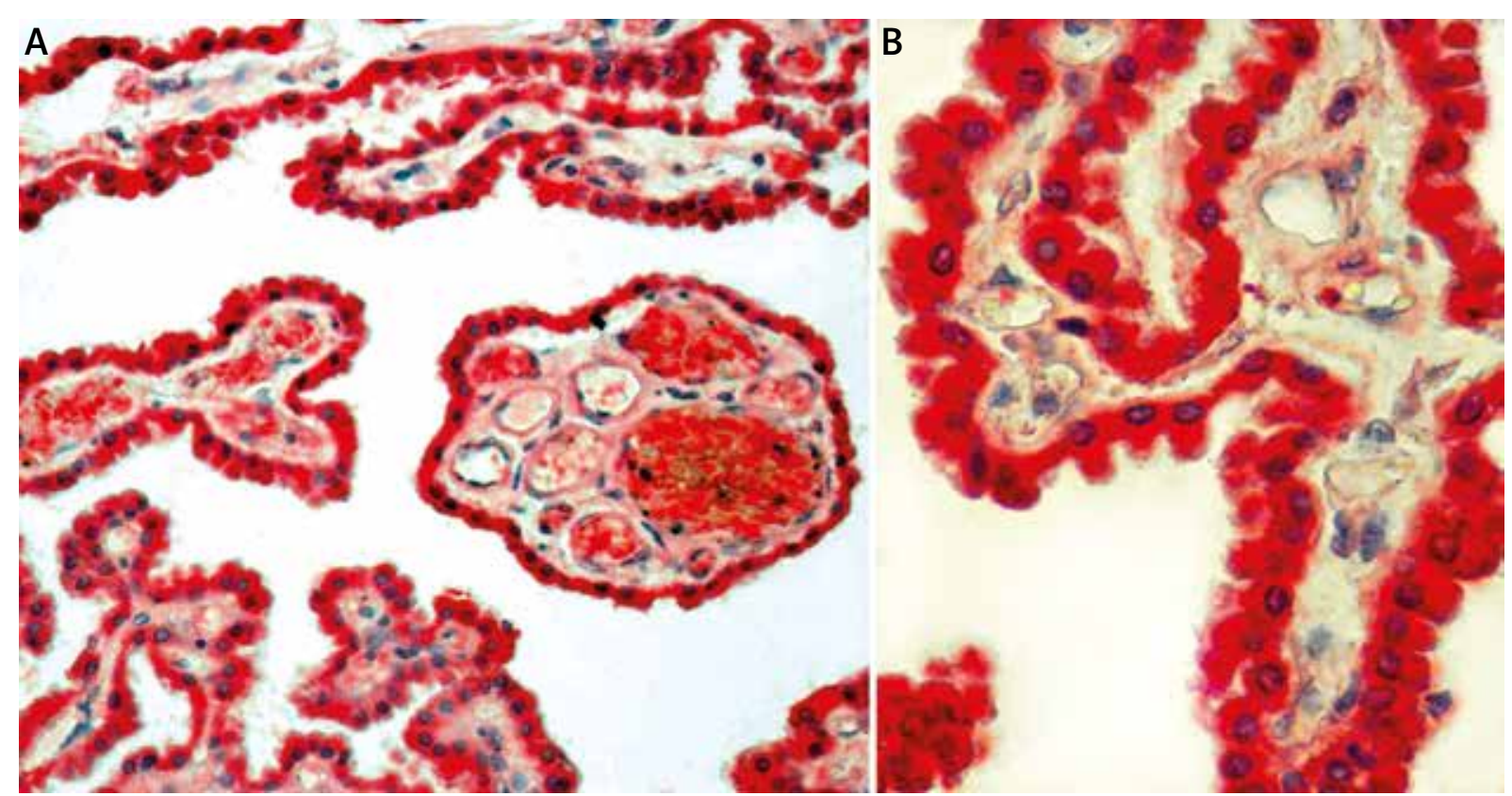

Fig. 5. ZAG present in epithelial cells of choroid plexus and in the lumen of blood vessels of the stroma.

A) Magn. $\times 100$; B) Magn. $\times 200$.

Intracellular localization of ZAG in hypertrophic astrocytes found in our study suggests also that ZAG protein as a lipid mobilizing factor could participate in the local lipid metabolism linked with the function of astrocytes in brain areas with myelin breakdown and/or in some types of nerve cells such as Purkinje cells of the cerebellum. It has been shown that both cell types (astrocytes and neurons) possess adrenergic receptors [12,22] that can bind ZAG [23,24].

Such local intracellular involvement of ZAG in the brain lipolysis could function as a process parallel to an independent neurotoxic effect of psychosine.

In addition, ZAG may serve in Krabbe's disease as a marker of cachexia [33]. Several authors report- 
Table II. Localization of zinc-alpha-2-glycoprotein (ZAG) in the brain of patients with Krabbe's disease and in controls

\begin{tabular}{lcc}
\hline ZAG localization & \multicolumn{2}{c}{ Patients } \\
\cline { 2 - 3 } & $\begin{array}{c}\text { Krabbe's } \\
\text { disease }\end{array}$ & Controls \\
\hline Extra-cellular & ++++ & - \\
\hline Peri-capillary & ++++ & - \\
\hline Blood vessel lumen & & \\
\hline Intra-cellular & ++++ & 0 \\
\hline Hypertrophied astrocytes & ++++ & - \\
\hline Purkinje cells & - & 0 \\
\hline Globoid cells & - & 0 \\
\hline Ramified microglia & ++++ & - \\
\hline Choroid plexus epithelium & - & \\
\hline $\begin{array}{l}\text { O-lack of cell type, - immuno-negative reaction, + slight immuno-positive } \\
\text { reaction, }++++ \text { strong immuno-positive reaction }\end{array}$
\end{tabular}

ed that the cachectic state is an independent risk factor for mortality in different chronic diseases including cancer [18], chronic heart failure [5], chronic obstructive pulmonary disease [32] or rheumatoid arthritis [20].

In summary, results of our study document the presence of ZAG in the brain of Krabbe's disease patients and suggest that this protein penetrates the brain through the blood-brain barrier.

Further studies are required to establish the association between the known inherited dysfunction of lysosomal enzyme and dysregulation of lipid metabolism in the brain of Krabbe's disease patients and answer numerous questions concerning the understanding of both complex processes and whether ZAG levels in body fluids of these patients will precede known clinical symptoms of the disease.

\section{References}

1. Arai H, Morikawa Y, Higuchi M, Matsui T, Clark CM, Miura M, Machida N, Lee VM, Trojanowski JQ, Sasaki H. Cerebrospinal fluid tau levels in neurodegenerative diseases with distinct tau-related pathology. Biochem Biophys Res Commun 1997; 236: 262-264.

2. Bao Y, Bing C, Hunter L, Jenkins JR, Wabitsch M, Trayhurn P. Zinc-alpha2-glycoprotein, a lipid mobilizing factor, is expressed and secreted by human (SGBS) adipocytes. FEBS Lett 2005; 579: 41-47.

3. Blennow K, Wallin A, Agren H, Spenger C, Siegfried J, Vanmechelen E. Tau protein in cerebrospinal fluid: a biochemical marker for axonal degeneration in Alzheimer disease? Mol Chem Neuropathol 1995; 26: 231-245.

4. Burgi W, Schmid K. Preparation and properties of Zn-alpha 2-glycoprotein of normal human plasma. J Biol Chem 1961; 236: 1066-1074.

5. Castillo-Martinez L, Colin-Ramirez E, Orea-Tejeda A, Gonzalez Islas DG, Rodriguez Garcia WD, Santillan Diaz C, Gutierrez Rodriguez AE, Vazquez Duran M, Keirns Davies C. Cachexia assessed by bioimpedance vector analysis as a prognostic indicator in chronic stable heart failure patients. Nutrition 2012; 28 : 886-891.

6. Choe LH, Dutt MJ, Relkin N, Lee KH. Studies of potential cerebrospinal fluid molecular markers for Alzheimer's disease. Electrophoresis 2002; 23: 2247-2251.

7. Davidsson P, Sjogren M, Anderasen N, Lindbjer M, Nilsson CL, Westman-Brinkmalm A, Blennow K. Stadies of the pathophysiological mechanisms in frontotemporal dementia by proteome analysis of CSF proteins. Brain Res Mol Brain Res 2002; 109: 128-133.

8. Davidsson P, Westman-Brinkmalm A, Nilsson CL, Lindbjer M, Paulson L, Anderasen N, Sjogren M, Blennow K. Proteome analysis of cerebrospinal fluid proteins in Alzheimer patients. Neuroreport 2002; 13: 611-615.

9. Duffner PK, Barczykowski A, Jalal K, Yan L, Kay DM, Carter RL. Early infantile Krabbe disease: results of World-Wide Krabbe Registry. Pediatr Neurol 2011; 45: 141-148.

10. Haq E, Giri S, Singh I, Singh AK. Molecular mechanism of psychosine-induced cell death in human oligodendrocyte cell line. J Neurochem 2003; 86: 1428-1440.

11. Hansson SF, Puchades M, Blennow K, Sjogren M, Davidsson P. Validation of a prefractionation method followed by two-dimentional electrophoresis - Applied to cerebrospinal fluid proteins from frontotemporal dementia patients. Proteome Sci 2004; $2: 7$.

12. Hertz L, Lovatt D, Goldman SA, Nadergaard M. Adrenoceptors in brain: cellular gene expression and effects on astrocytic metabolism and [Ca +2]i. Neurochem Int 2010; 57: 411-420.

13. Hirai K, Hussey HJ, Barber MD, Price SA, Tisdale MJ. Biological evaluation of a lipid-mobilizing factor isolated from the urine of cancer patients. Cancer Res 1998; 58: 2359-2365.

14. Igisu H, Suzuki K. Progressive accumulation of toxic metabolite in genetic leukodystrophy. Science 1984; 224: 753-755.

15. Kobayashi T, Shinoda H, Goto I, Yamanaka T, Suzuki Y. Globoid cell leukodystrophy is a generalized galactosylsphingosine (psychosine) storage disease. Biochem Biophys Res Commun 1987; 144: 41-46.

16. Kolodny EH. Globoid leukodystrophy. In: Vinken PJ, Bruyn GW (ed.). Handbook of Clinical Neurology: Neurodystrophies and Neurolipidoses. Elsevier, Amsterdam 1996; pp. 187-210.

17. Mracek T, Ding Q, Tzanavari T, Kos K, Pinkney J, Wilding J, Trayhurn P, Bing C. The adipokine zinc-alphaz-glycoprotein (ZAG) is downregulated with fat mass expansion in obesity. Clin Endocrinol (Oxf) 2010; 72: 334-341.

18. Mracek T, Stephens NA, Goa D, Bao Y, Ross JA, Ryden M, Arner P, Trayhurn P, Fearon KC, Bing C. Enhanced ZAG production by subcutaneous adipose tissue is linked to weight loss in gastrointestinal cancer patients. Br J Cancer 2011; 104: 441-447. 
19. Rafi MA, Luzi P, Zlotogora J, Wenger DA. Two different mutations are responsible for Krabbe disease in the Druze and Moslem Arab populations in Israel. Hum Genet 1996; 97: 304-308.

20. Rall LC, Roubenoff R. Rheumatoid cachexia: metabolism abnormalities, mechanisms and interventions. Rheumatology (Oxford) 2004; 43: 1219-1223.

21. Roher AE, Maarouf CL, Sue LI, Hu Y, Wilson J, Beach TG. Proteomics-derived cerebrospinal fluid markers of autopsy-confirmed Alzheimer's disease. Biomarkers 2009; 14: 493-501.

22. Russell ST, Hirai K, Tadale MJ. Role of beta 3-adrenergic receptors in the action of a tumour lipid mobilizing factor. Br J Cancer 2002; 86: 424-428.

23. Russell ST, Tisdale MJ. The role of glucocorticoids in the induction of zinc-alpha2-glycoprotein expression in adipose tissue in cancer cachexia. Br J Cancer 2005; 92: 876-881.

24. Russell ST, Zimmerman TP, Domin BA, Tisdale MJ. Induction of lipolysis in vitro and loss of body fat in vivo by zinc-alpha 2-glycoprotein. Biochem Biophys Acta 2004; 1636: 59-68.

25. Sanders PM, Tisdale MJ. Effect of zinc-alpha2-glycoprotrin (ZAG) on expression of uncoupling proteins in skeletal muscle and adipose tissue. Cancer Letters 2004; 212: 71-81.

26. Sickmann A, Dormeyer W, Wortelkamp S, Woitalla D, Kuhn W, Meyer HE. Towards a high resolution separation of human cerebrospinal fluid. J Chromatogr B Analyt Technol Biomed Life Sci 2002; 771: 167-196.

27. Sjögren M, Minthon L, Davidsson P, Granérus A-K, Clarberg A Vanderstichele $H$, Vanmechelen E, Wallin A, Blennow K. CSF levels of tau, beta-amyloid (1-42) and GAP-43 in frontotemporal dementia, other types of dementia and normal aging. J Neurol Trans 2000; 107: 563-579.

28. Sjögren M, Minthon L, Davidsson P, Granérus A-K, Clarberg A, Vanderstichele $\mathrm{H}$, Vanmechelen E, Wallin A, Blennow K. Cytoskeleton proteins in CSF distinguish frontotemporal dementia from AD. Neurology 2000; 54: 1960-1964.

29. Szymańska K, Lugowska A, Laure-Kamionowska M, Bekiesińska-Figatowska M, Gieruszczak-Białek D, Musielak M, Eichler S, Giese AK, Rolfs A. Diagnostic difficulties in Krabie disease: a report of two cases and review of literature. Folia Neuropathol 2012; 50: 346-356.

30. Tada T, Ohkubo I, Niwa M, Sasaki M, Tateyama H, Eimoto T. Immunohistochemical localization of Zn-alpha 2-glycoprotein in normal human tissues. J Histochem Cytochem 1991; 39: 1221-1226.

31. Tapasi S, Padma P, Setty OH. Effect of psychosine on mitochondrial function. Indian J Biochem Biophys 1998; 35: 161-165.

32. Tisdale MJ. Molecular pathways leading to cancer cachexia. Physiology (Bethesda) 2005; 20: 340-348.

33. Todorov PT, McDevitt TM, Meyer DJ, Ueyama H, Ohkubo I, Tis dale MJ. Purification and characterization of a tumour lipid-mobilizing factor. Cancer Res 1998; 58: 2353-2358.

34. Wenger DA, Suzuki K, Suzuki Y, Suzuki K. Galactosylceramide lipidosis: globoid cell leukodystrophy (Krabbe disease). In: Seriver CR, Beaudet AL, Sly WS, Valle D (eds.). The Metabolic and Molecular Bases of Inherited Disease. McGraw-Hill, New York 2001; pp. 3669-3694.

35. Yuan X, Russell T, Wood G, Desiderio DM. Analysis of the human lumbar cerebrospinal fluid proteome. Electrophoresis 2002; 23 1185-1196. 